\title{
ROMAN MILITARY IN THE VESUVIUS AREA
}

\author{
Salvatore Ortisi
}

With the following interim report I will outline the type and extent of the military presence in the Vesuvius-area, focussing especially on Herculaneum and Pompeii. ${ }^{1}$ I am grateful to Stefano DeCaro, PierGiovanni Guzzo and Antonio D'Ambrosio as well as Mariarosaria Borriello, who gave me full assistance in the assessment of this material and the finds.

The ultimate aim of this study is not a mere antiquarian study of Roman arms and weaponry, but, on the basis of material from the cities in the Vesuvius area, to compare and contrast archaeological and historical evidence in order to assess the role of the military in a primarily civilian region of the Roman Empire. There is a significant amount of evidence - both epigraphical and iconographical - that attests the presence of regular military personnel in the Vesuvian cities. Numerous graffiti primarily indicate the presence of Praetorians and Fleet soldiers. ${ }^{2}$ Honorific and dedicatory inscriptions regularly attest the presence of higher ranking officers. ${ }^{3}$ Occasionally, however, these are also attested by funerary monuments, such as the one of the Octavii near the Porta di Nocera at Pompeii (fig. 1). ${ }^{4}$

\footnotetext{
1 The study of military equipment from the towns in the Vesuvius area goes back to a research project funded by the Fritz-Thyssen-Foundation which started at the Ludwig-Maximilians-Universität in Munich. It is now continued at the Department of Archaeology of the University of Cologne. We owe thanks to Christoph Rummel, Nottingham, for checking the English version of this contribution.

${ }^{2}$ Vgl. CIL IV 1994; 2145; 8405.

3 Turranius Proculus Gellianus: CIL X 797; G. Fiorelli, Descrizione di Pompei (Napoli 1875), 256.

${ }^{4}$ A. D'Ambrosio and S. De Caro, eds., Un impegno per Pompei. Fotopiano e documentazione della necropoli di porta Nocera. Studi e contributi (Milan 1983), sheet 13 OS; Notizie degli Scavi (1958), 157 n. 394; H. Gabelmann, 'Römische Grabbauten in Italien und den Nordprovinzen', in U. Höckmann and A. Krug, eds., Festschrift fir Frank Brommer (Mainz 1977), 108 pl. 33,1; P. Zanker, 'Grabreliefs römischer Freigelassener', Jahrbuch DAI 90 (1975), 283 fig. 15; P. Castrén, Ordo Populusque Pompeianus. Acta Instituti Romani Finlandiae 8 (Rome 1975), 199 n. 285,2.
} 


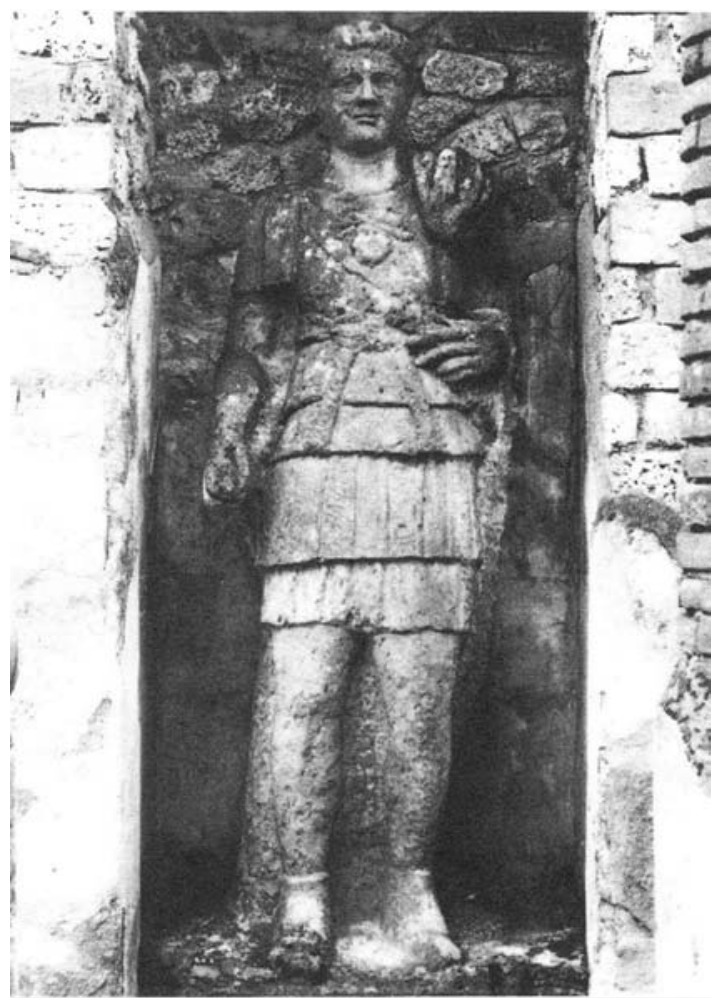

Fig. 1. The monument of the Octavii near the Porta di Nola at Pompeji (from: A. D'Ambrosio and S. De Caro, eds., Un impegno per Pompei [Milano 1983], n. 13 OS)

Of special interest in this respect is the funerary district of the Praetorians in front of the Porta di Nola. ${ }^{5}$ This small cemetery, situated on a narrow and apparently public strip of land, was in use for an extended period of time. Both the funerary monuments, as well as numerous Graffiti attest the mainly occasional presence of Praetorians.

Apart from regular bases and forts, the best way to identify soldiers archaeologically is through their equipment, and especially through their weapons and armour. A general outline of the types of artefacts recovered during excavations allows a first insight in the presence of military forces in the Vesuvian cities.

\footnotetext{
${ }^{5}$ St. De Caro, 'Scavi nell'area fuori Porta Nola a Pompei', Cronache Pompeiane 5 (1979), 85ff.
} 
Initially, Roman military equipment must be divided into three main groups. These are: offensive equipment, defensive equipment and parade equipment. The most characteristic equipment used for offensive purposes is the short-sword, the gladius (fig. 2, 1). Furthermore, there is the dagger (fig. 2, 3-4) and the associated belt, the cingulum militare (fig. 2, 7-8). Even though the gladius frequently features as a stabbing weapon in gladiatorial iconography, ${ }^{6}$ it was primarily a military weapon. A general theory, identifying all the gladii found in the Vesuvian cities as gladiatorial weapons, should be considered somewhat simplistic. ${ }^{7}$ Indeed, these characteristic swords could only be identified as gladiatorial with some certainty if they were found in combination with clearly identifiable gladiatorial equipment such as shoulder-armour, shin guards, or typical types of helmet. Gladii associated with a dagger and a cingulum, on the other hand, do nearly certainly point towards a military context. Among the different types of spear points found, only the pilum was standard equipment of Roman legionaries. Simple javelins or spears with leaf-shaped points, however, can easily be interpreted as huntingweapons - especially in the context of rural villas.

Amongst the defensive equipment, helmets and shields serve the archaeologist as primary indicators of a military presence. In view of the artefacts from the Vesuvian cities in general, and especially of the large numbers of gladiatorial helmets found at Pompeii, ${ }^{8}$ it is once again important to make a clear distinction between military and gladiatorial helmets. As close investigations of the artefacts show, however, there are distinct differences in shape and manufacturing techniques of the individual pieces. On this basis, military helmets can be separated from gladiatorial ones with some degree of certainty. The only shield from the Vesuvian cities that I know of, however, can hardly be compared to those found in the forts and camps of the North-West Provinces ${ }^{9}$ and should therefore rather be interpreted as a parade or gladiatorial shield - unless this particular type was used by the fleet at Misenum. ${ }^{10}$

6 A. La Regina, ed., Sangue e Arena (Roma 2001), 356 nn. 70-71.

7 G. Ulbert, 'Gladii aus Pompeji', Germania 47 (1969), $124 f$.

${ }^{8}$ La Regina 2001, op. cit. (n. 6), 370-389 n. 94-121.

${ }_{9}^{9}$ La Regina 2001, op. cit. (n. 6), 382 n. 107.

${ }^{10}$ S. Ortisi, 'Pompeji und Herculaneum - Soldaten in den Vesuvstädten', Carnuntum Fahrbuch (2005), $145 \mathrm{ff}$; Th. Fischer, 'Ein römischer Legionarshelm des ersten Jahrhunderts n. Chr. aus dem Po bei Cremona im Römisch-Germanischen Museum zu Köln', Kölner Fahrbuch 37 (2004), 61ff. 

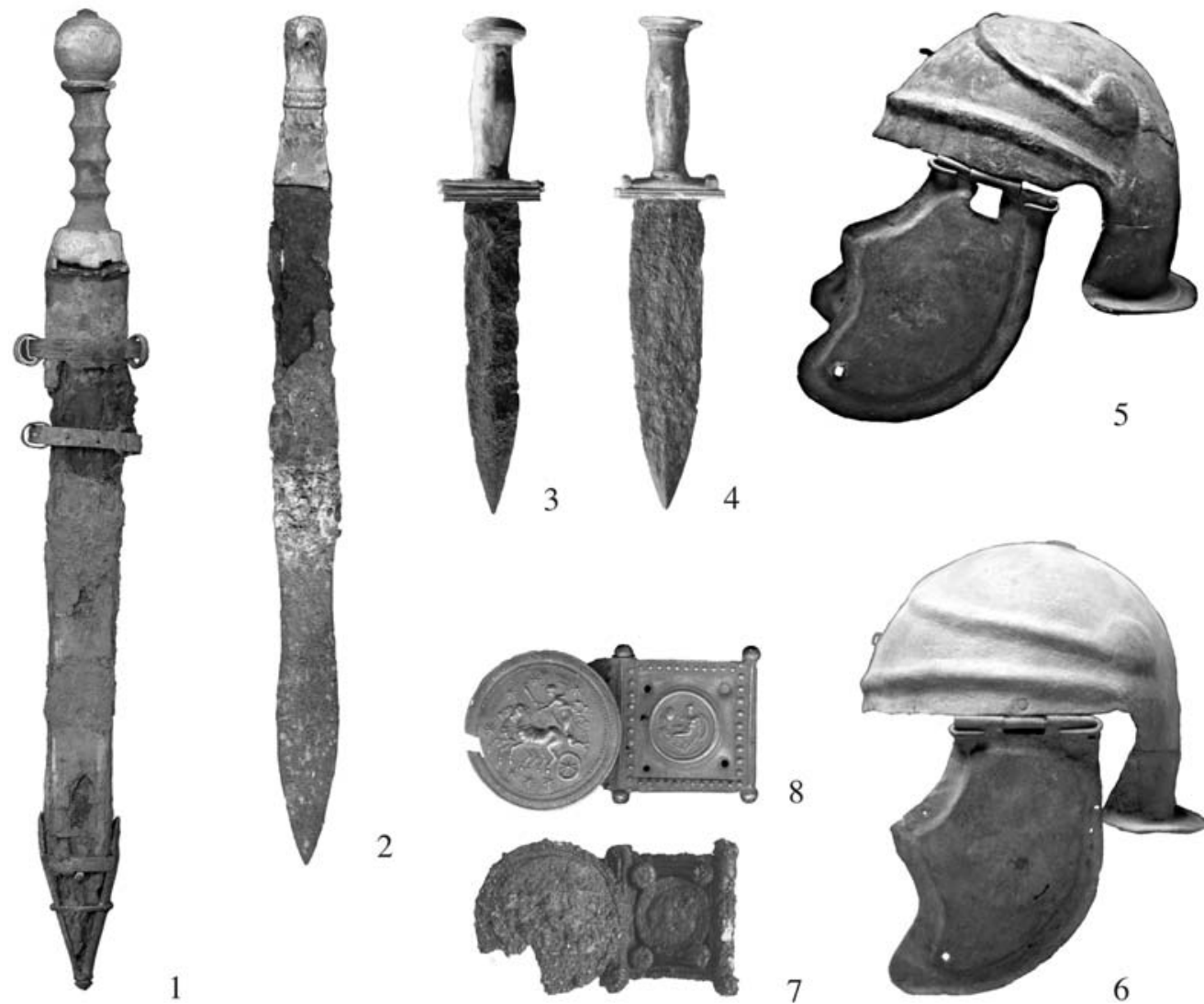

2
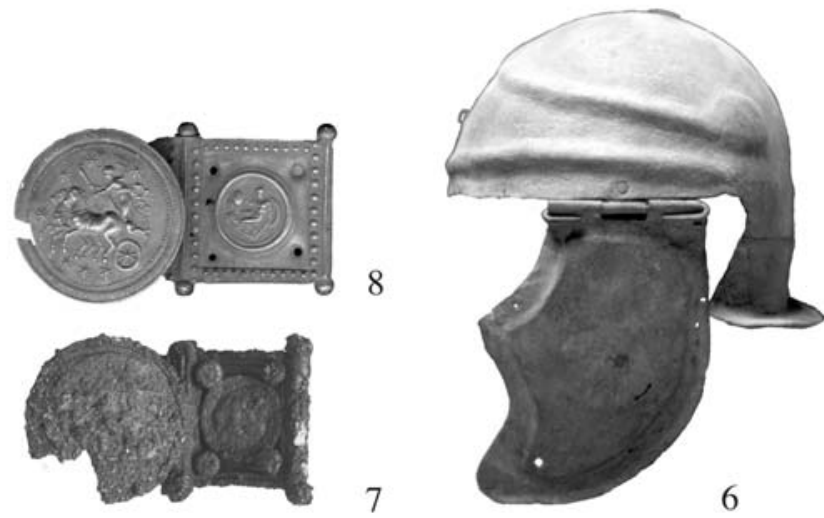

Fig. 2. Military equipment from the Vesuvian cities. 1-6 scale 1:4; 7-8 scale 1:2 (silver). (Fig. 1-2; 5-8: Ortisi; 3-4: La Regina 2001, op. cit. (n. 6), 391 nrs. 127-128) 
Parade equipment, characteristic of Roman cavalry units, must be treated as a special case. ${ }^{11}$ In the Vesuvian cities, this equipment is represented by only a few individual artefacts. Parade swords, so-called parazonia (fig. 2, 2), on the other hand, have been found in significantly larger numbers. ${ }^{12}$ In the provinces these swords are hardly ever found in contexts of a military nature. It appears likely, therefore, that they are to be associated with honorific posts of a military nature, probably the post of the tribunus militum a populo.

Horse-harnesses form a specific problem in this study. As Roman military units were primarily stationed along the Imperial frontiers, military equipment has been studied for a long time by archaeologists dealing with the Roman frontier provinces. As parts of horse-harness have been found in almost every Roman military fort or base, as well as in towns and villages characterised by a strong military influence, harness-fittings have long been seen as an archaeological indicator of military presence. ${ }^{13}$ The finds from the Vesuvian cities, however, clearly show that this traditional interpretation must be reconsidered. It appears that horse-harnesses, sometimes elaborately decorated, were generally used by higher-status households. The current focus on the frontier provinces, as caused by the traditional emphases of archaeological research, has thus produced a somewhat misleading understanding of historic developments. It appears that the use of harness-fittings was not of an exclusively military nature. On the contrary, it appears that the majority of peregrine cavalry soldiers copied the design of their horse-harnesses from the Roman upper classes - probably from their own officers.

To summarize: for the purposes of this study, all finds of weapons and armour that were used exclusively, or virtually so, by the military, are taken as archaeological indicators for a Roman military presence.

${ }^{11}$ J. Garbsch, Römische Paraderïstungen (München 1978); G. Waurick, in Antike Helme. Sammlung Lipperheide und andere Bestände des Antikenmuseums Berlin. Römisch-Germanisches Zentralmuseum Monographien 14 (Mainz 1988), 345ff.

12 M. Feugère, Les Armes des Romains de la République à l'Antiquité tardive (Paris 1993), 160f. with fig. left.

${ }_{13}$ M. Mackensen, 'Militärische oder zivile Verwendung rühkaiserzeitlicher Pferdegeschirranhänger aus der Provinz Africa Proconsularis und den Nordwestprovinzen', Germania 79 (2001), 325ff.; E. Deschler-Erb, Ad Arma! Römisches Militär des 1. Fahrhunderts n. Chr. in Augusta Raurica. Forschungen in Augst 28 (Augst 1999), 49ff. 


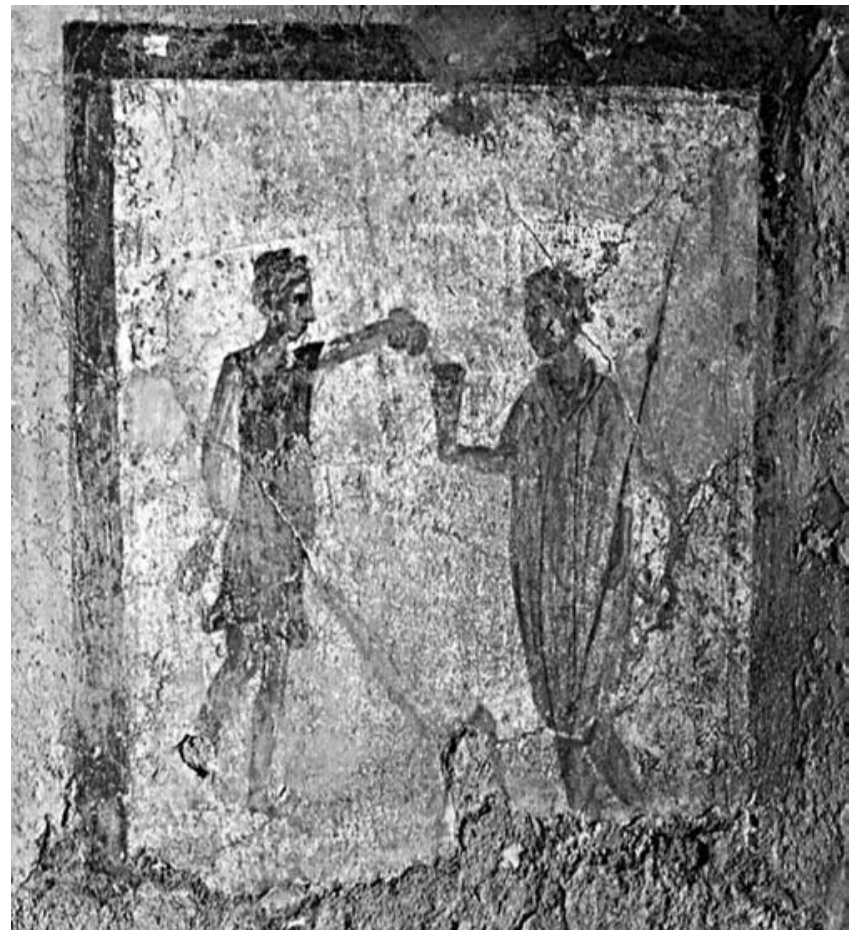

Fig. 3. Soldier with pilum (from: Th. Fröhlich, Lararien- und Fassadenbilder in den Vesuvstädten [Mainz 1991], pl. 19, 2)

These are gladii, daggers, cingula and certain types of helmet. One example of a pilum is known from a fresco in Pompeii (fig. 3), but there are no surviving original artefacts.

In order to grasp the extent of the military presence in the cities studied, and thus the influence the soldiers may have had on the socioeconomical development of these cities, the number of weapons and arms found, as well as the locations of findspots must be discussed in more detail. The documentation of artefacts together with the study of the excavation reports shows that at least 30 offensive weapons were found in the Vesuvian cities. ${ }^{14}$ Fittings and buckles of cingula occur

14 S. Ortisi, 'Gladii aus Pompeji, Herculaneum und Stabia', Germania 84 (2006), 369ff. 
significantly less often. ${ }^{15}$ Fragments and parts of defensive equipment finally are relatively rare. ${ }^{16}$

To date, there are no significant remains of shields, breastplates, chain- or scalemail. Several spear-points are referred to in excavation reports - yet only a few have been preserved. ${ }^{17}$ The reason why no remains of a pilum have been found so far is likely to be the high level of corrosion of all iron finds in this area. Considering the fact that the significant number of elements of horse-harnesses, as well as the parade-equipment, should mainly be associated with civilian contexts, the number of 'real' military artefacts is small. All in all, there is evidence for only about twelve soldiers in the contexts associated with the catastrophic destruction of the Vesuvian cities. This impression is further differentiated by a closer study of the general circumstances, in which these weapons were found.

The first case study comes from Pompeii. It regards objects found in the so-called 'caserma dei gladiatori.' The excavations of the quadriporticus behind the great theatre are documented in detailed excavation reports. ${ }^{18}$ Work was begun in 1766 and continued for two years until 1768. Initially, the investigations focussed on the rooms situated along the eastern wing of the porticus. These yielded several helmets, shinguards and other items of gladiatorial armour, as well as leg-irons. In December 1767, the excavations shifted to the north-western corner of the quadriporticus. In one of the sottoscala rooms, 18 close-packed human skeletons were discovered. Among the finds associated with the bodies were significant amounts of gold jewellery and semi-precious stones, as well as two D-shaped belt buckles and 2 helmets, one pushed into the other. When work recommenced in January 1768, a round-shield was found in the immediate vicinity of the helmets. This was accompanied by a parazonium with a rounded pommel and an ivory hilt, as well as two

${ }^{15}$ E. Künzl, 'Cingula aus Campanien', in Actes $d u V I^{e}$ Colloque International sur les bronzes antiques (Lyon 17-21 mai 1976), (Lyon 1977), 83ff.; E. Künzl, 'Cingula di Ercolano e Pompei', Cronache Pompeiane 3 (1977), 177ff.; E. Künzl, 'Gladiusdekorationen der frühen römischen Kaiserzeit: Dynastische Legitimation, Victoria und Aurea Aetas', Jahrbuch RGZM 43 (1996), 383ff. esp. 426; 433; 462 nrs. C25-27; 465 nrs. P 9-10; M. Junkelmann, Die Reiter Roms I (Mainz 1990), 226f. fig. 243; M.C. Bishop and J.C.N. Coulston, Roman Military Equipment (London 1993), 96f., fig. 59,13.

${ }^{16}$ H.R. Robinson, The Armour of Imperial Rome (London 1975), 65ff., figs. 150-151; Ortisi 2003, op. cit. (n. 10), 145-147.

${ }_{17}$ G. Fiorelli, Pompeianarum Antiquitatum Historia 1 (Napoli 1860), 217.

${ }^{18}$ Fiorelli 1860, op. cit. (n. 17), 212-217; Ortisi 2003, op. cit. (n. 10), 143. 
daggers. Adjacent to these lay remains of leather with gold ornaments, several large iron knives and daggers as well as significant amounts of wood - some combined with gold- and bronze-sheets. The description of the helmets is detailed enough to allow an identification with the two pseudo-attic helmets stored in the Museo Nazionale at Naples (fig. 2, 5-6). Equally well known and published on several occasions are the round-shield and the two daggers. ${ }^{19}$ The parazonium mentioned in the excavation report appears to be the smaller one of two preserved gladii of the Pompeii type, kept in the stores of the Museo Nazionale (fig. 2, 1).

Yet there are questions regarding the interpretation of these finds. In the 19th and early 20th century, archaeologists identified the helmets and daggers, as well as the gladii found in the Vesuvian cities, regardless of their original find contexts as gladiatorial armour. ${ }^{20}$ It is remarkable, however, that offensive equipment was only found in one single room of the entire so-called 'caserma dei gladiatori'. The numerous finds of gladiatorial helmets, shinguards and shoulder-plates in the eastern wing of the quadriporticus were never associated with any offensive armour such as stabbing or cutting swords. It is likely, therefore, that the room discussed above is to be interpreted as an armoury or guard-chamber of the gladiators' barracks. It seems appropriate to identify the two helmets as well as the gladius and perhaps the two daggers with bone hilts and the belt-buckles, as the armour of at least two guards, as these are distinctly different from the remaining gladiatorial equipment, found at this site. ${ }^{21}$ Unfortunately, it is not possible to reconstruct whether the guards were in fact amongst the bodies found, i.e. whether the military equipment was found 'on' the soldiers using it. The helmets, in any case, were pushed into one another, and so cannot have been worn at the time of the Pompeii disaster. To my knowledge, no parallels to these pseudo-attic helmets are known. Possibly these light helmets, which appear to have been made of a metal sheet and were thus of little use for gladiatorial combat, were of a particular type used by the Fleet. On the basis of these findings one may conclude that the guardians may well have been recruited amongst the soldiers of the nearby fleet-

19 A. d'Ambrosio, P.G. Guzzo, M. Mastroroberto, eds., Storie da un'Eruzione. Pompei, Ercolano, Oplontis (Milano 2003), 247 n. IV, 19-21.

${ }^{20} \mathrm{~J}$. Overbeck, Pompë̈. In seinen Gebäuden, Alterthümern und Kunstwerken (Leipzig 1856), 152f.; A. Mau, Pompeji in Leben und Kunst (Leipzig 1908, 2nd ed.), $168 f$.

21 Ortisi 2003, op. cit. (n. 10) 145. 
base at Misenum and detached to Pompeii for this particular purpose during an extended period.

The remains of a soldier who died in active service were uncovered in Herculaneum recently: in front of one of the rooms of the substructures under a temple precinct on the ancient beach, the skeleton of a soldier was excavated in 1982. ${ }^{22}$ The body lay on its front and wore a gladius on the right and a dagger on the left. It appears that the man was carrying a sack or leather pouch filled with carpenters' tools (a hammer and two chisels) on his back. This indicates that he is unlikely to have been of a higher rank than a gregalis or immunis. The contents of a purse were found beneath the straps of his apron. Amongst the coins were two aurei - a substantial sum of money for a simple soldier. Of further interest are the silver cingulum fittings which are evidently similar to the known ones from the Vesuvian cities, even though they have not yet been restored..$^{23}$ The striking similarities between these cingula have virtually no parallels outside the Vesuvian cities. They were probably manufactured specifically for the fleet in workshops in the Misenum area - or at least greater Campania.

The fact that this soldier was buried carrying a bag of tools is an indicator that he was on his way for a specific task, and only happened to be in Herculaneum at the time of the disaster by coincidence.

Apart from active soldiers, several veterans are attested in the Vesuvian cities. Numerous graffiti indicate their presence, but the main evidence for the presence of veterans consists of military diplomas. ${ }^{24}$ They attest the honorary discharge of soldiers either from the fleet based at Misenum or from the Legions I and II adiutrices, which were recruited from fleet soldiers. All the documents date from years between $\mathrm{AD} 52$ and 71 .

Yet the diplomas and the graffiti are not the only source for the presence of veterans in this area. The majority of the gladii known from Pompeii and Herculaneum were found during the earlier excavations.

${ }^{22}$ U. Pappalardo, Pompeii, Herculaneum, Stabiae 1 (1983), 344ff.; J. Judge, 'On the slope of Vesuvius. A buried Roman town gives up its dead', National Geographic 162, 6 (1982), 687ff.; R. Gore, '2000 Years of Silence. The dead do tell tales at Vesuvius', National Geographic 165, 5 (1984), 557ff.; E. De Carolis, in D'Ambrosio, Guzzo, Mastroroberto 2003, op. cit. (n. 19), $137 f$.

${ }^{23}$ P.G. Guzzo, A. Wieczorek, eds., Pompeji. Die Stunden des Untergangs. 24. August 79 n. Chr. (Milan 2004), 70 fig. 15; Künzl 1996, op. cit. (n. 15), 462 nrs. C 25-27; Künzl 1976, op. cit. (n. 15), 83-86; Künzl 1977, op. cit. (n. 15), 177-197.

${ }^{24}$ CIL X 769, 867, 1402; XVI 7, 8 (?). 
Consequently, an accurate reconstruction of their original contexts is difficult. An exception to this rule is the sword found at the Villa dei Misteri: it was found in a room of the agricultural wing of the villa. ${ }^{25}$ Both this situation and the fact that it had been damaged in antiquity (only one of the fastening rings remained) suggest that it is unlikely to have belonged to a soldier in active duty. At the same time, however, its association with the agricultural wing of the villa makes it unlikely that it was part of the armour of the patronus. The most likely interpretation, therefore, is that it was the weapon of a veteran who was presumably employed in some way or other by the owner of this estate. Several examples from different villae of the Vesuvius region indicate that veterans were frequently employed as bodyguards of important and wealthy individuals. An individual wearing a gladius and a doctor were found in the immediate vicinity of a group of richly dressed bodies in front of the villa marittima at Bottaro on the mouth of the Sarno. ${ }^{26}$ A similar observation could be made at the 'Villa of Livia' at Oplontis. ${ }^{27}$

In both cases, only gladii were found. There are no indications of daggers or cingula in the documentation whatsoever. The presence of these swords could of course be due to the fact that active soldiers may have accompanied officers' families beyond the military sphere of a Roman army (or naval) base. The absence of any other form of military equipment (esp. cingula), however, does seem to favour the interpretation that the swords belonged to veterans.

There is ample epigraphical, iconographical and archaeological evidence for Roman military presence in the Vesuvian cities. Yet the relatively small number of weapons and military equipment discovered in the destruction layers of August AD 79 indicates that the actual number of military personnel in the city was relatively small - despite the close proximity of the important fleet-base at Misenum. Iconographical evidence and numerous graffiti, however, indicate that soldiers must at the very least have been frequent customers of the entertainment sector. An interesting aspect of the material found are specific pieces of equipment, which appear to have been manufactured in workshops

\footnotetext{
${ }^{25}$ A. Maiuri, LaVilla dei Misteri (Rome 1931), 236; 237 fig. 102 (room n. 35).

${ }^{26} \mathrm{~J}$. Matrone, Précis historique sur les fouilles exécuteés par l'ingénieur 7. Matrone près de l'ancienne bourgade de la Marine de Pompéi (Naples 1909), $7 \mathrm{ff}$.

27 A. D'Ambrosio, Gli ori di Oplontis (Napoli 1987), 30f.; D’Ambrosio, Guzzo, Mastroroberto 2003, op. cit. (n. 19), 79 Fig.
} 
specific to this region. A significant amount of fleet soldiers, most of whom appear to have come from the Eastern half of the Empire, seem to have remained in the Gulf of Naples area after their discharge. As the evidence from the Vesuvian cities clearly shows, these veterans proceeded to play an active and significant role in the economical and social life of these urban centres. 